\title{
Influence of Estrus Synchronization Protocols on Serum Protein during Reproductive Cycle in Kilakarsal Ewes
}

\author{
M. Sundara Vinayaki*, V. S. Gomathi, K. Loganathasamy and \\ Pasupathi, Karu Tanuvas
}

Department of Veterinary Physiology \& Biochemistry, Veterinary College \& Research Institute, Tirunelveli - 627 358, TamilNadu, India

*Corresponding author

\section{A B S T R A C T}

\begin{abstract}
A research work was undertaken to induce estrus synchronization in Kilakarsal ewes, using chitosan nanoconjugated GnRH and to assess its efficacy and economic feasibility under semi intensive farming conditions by comparing the same with various drug protocols. Ewes in the control were not given any treatment. The group I ewes were treated with CIDR alone. The group II ewes were treated with CIDR and GnRH. The group III ewes were treated with CIDR and $\mathrm{PGF}_{2} \alpha$. The group IV ewes were treated with CIDR, $\mathrm{PGF}_{2} \alpha$ and $\mathrm{GnRH}$. The group V ewes were treated with CIDR and Nanoconjugated GnRH. The group VI ewes were treated with CIDR, $\mathrm{PGF}_{2} \alpha$ and Nanoconjugated GnRH. The serum total protein level during the off season on the day of CIDR insertion, CIDR removal, day of estrum, day of mating and on the $70^{\text {th }}$ day of pregnancy in control and different treatment groups ranged from $7.23 \pm 0.17$ to $7.45 \pm 0.11,6.71 \pm 0.10$ to $7.06 \pm 0.11,8.00 \pm 0.22$ to $8.88 \pm 0.14,7.29 \pm 0.19$ to $7.55 \pm 0.11$ and $6.53 \pm 0.26$ to $6.88 \pm 0.22 \mathrm{~g} / \mathrm{dL}$, respectively. The values observed in groups II and III were significantly higher $(\mathrm{P}<0.05)$ when compared with that of the other groups on the day of CIDR removal. On the day of estrum the serum protein values were found to be significantly $(\mathrm{P}<0.05)$ lowest in control group when compared with that of the other groups on the same day sampling. It was concluded that the novel protocol of combining CIDR with or without $\mathrm{PGF}_{2} \alpha$ and nanoconjugated $\mathrm{GnRH}$ was very safe and effective to induce intense estrus synchronization, achieve better \% of reproductive performance and may be adopted in the field to increase sheep production.
\end{abstract}

\section{Introduction}

Sheep plays a major economic role in the marginal and landless labourers because of its multiple utility as mutton, wool, milk, skin and manure. The sheep rearing farmers are increasing gradually and this is witnessed by the increased population by 14.1 per cent than previous census [74.26 million - Anonymous (2019)]. Ewes are seasonally polyestrous animal with effective means of management three lambing could be achieved in two years. But in field condition the farmers failed to obtained this three lambs within two years.

The recent technology of estorus synchronization to improve the fertility and programmed breeding is inevitably assisting the farmers and entrepreneurs to improve the farm profit. Blood biochemical values are an 
important tool for assessment of the health status of animals and this may vary even in healthy animals due to differences in factors such as sex, season and phase of estrus cycle (Tamukai et al., 2011 and Yaqub et al., 2011). Hence, the present study was undertaken to assess the biochemical profile of different estrus synchronization protocols in comparison with Nanoconjugated GnRH in Kilakarsal ewes.

\section{Materials and Methods}

The trial was conducted at Veterinary College and Research Institute, Tirunelveli. The experiment was conducted in off season. 140 Kilakarsal ewes were randomly divided into seven groups with 20 ewes in each. group. The group I ewes were treated with CIDR alone. The group II ewes were treated with CIDR and GnRH. The group III ewes were treated with CIDR and $\mathrm{PGF}_{2} \alpha$. The group IV ewes were treated with $\mathrm{CIDR}, \mathrm{PGF}_{2} \alpha$ and GnRH. The group V ewes were treated with CIDR and Nanoconjugated GnRH. The group VI ewes were treated with CIDR, $\mathrm{PGF}_{2} \alpha$ and Nanoconjugated GnRH. Group VII kept as control without any treatment. Blood samples were collected five times as furnished through jugular puncture, from all the treatment groups during various stages of the experiment as listed below. From the samples serum was separated and subjected to assay of various biochemical parameters and the values were recorded.

First collection : On the day of CIDR insertion.

Second collection : On the day of CIDR removal.

Third collection : On the day of estrum. Fourth collection : On the day of mating. Fifth collection : $\quad$ On the $70^{\text {th }}$ day of pregnancy.
The serum total protein concentration was estimated using EPOCH Microplate Spectrophotometer at $546 \mathrm{~nm}$ by direct biuret method, as described by Lubran (1978). The data were subjected to one - way analysis of variance (ANOVA) and post hoc analysis was carried out using Duncan's test for multiple comparisons using SPSS software version 20 for Windows. The mean serum total protein level for the control and other groups of ewes at different phases of reproductive cycle was analysed. The serum total protein level on the day of CIDR insertion, CIDR removal, day of estrum, day of mating and on the $70^{\text {th }}$ day of pregnancy in control and different treatment groups ranged from $7.23 \pm 0.17$ to $7.45 \pm 0.11$, $6.71 \pm 0.10$ to $7.06 \pm 0.11, \quad 8.00 \pm 0.22$ to $8.88 \pm 0.14,7.29 \pm 0.19$ to $7.55 \pm 0.11$ and $6.53 \pm 0.26$ to $6.88 \pm 0.22 \mathrm{~g} / \mathrm{dL}$, respectively.

The values observed in groups II and III were significantly higher $(\mathrm{P}<0.05)$ when compared with that of the other groups on the day of CIDR removal. On the day of estrum the serum protein values were found to be significantly $(\mathrm{P}<0.05)$ lowest in control group when compared with that of the other groups on the same day sampling.

However, the values increased from the day of CIDR insertion to the day of estrum and thereafter tended to decline as observed on the day of mating and $70^{\text {th }}$ day of pregnancy and the variations were statistically significant. While the same trend was observed in all the treatment groups the highest values were on the day of estrum in all the groups and ranged from $8.00 \pm 0.22$ to $8.88 \pm 0.14 \mathrm{~g} / \mathrm{dL}$ in Kilakarsal ewes. It is obvious from the present study that the $\mathrm{PGF}_{2} \alpha$ with nano conjugated $\mathrm{GnRH}$ and other treatment did not differ significantly during different phases of estrus cycle hence the nano conjugated prostaglandin did not povoke any adverse reaction and can safely be used for synchronization. 
Table.1 Effect of different estrus synchronization on the serum protein $(\mathrm{g} / \mathrm{dL})$ during reproductive cycle in Kilakarsal ewes during off season

\begin{tabular}{|c|c|c|c|c|c|c|c|}
\hline $\begin{array}{l}\text { Different } \\
\text { stages of } \\
\text { reproductive } \\
\text { cycle }\end{array}$ & $\begin{array}{l}\text { Group I } \\
\text { CIDR }\end{array}$ & $\begin{array}{l}\text { Group II } \\
\text { CIDR with } \\
\text { GnRH }\end{array}$ & $\begin{array}{l}\text { Group III } \\
\text { CIDR with } \\
\text { PGF }_{2} \alpha\end{array}$ & $\begin{array}{c}\text { Group IV } \\
\text { CIDR, } \\
\text { PGF }_{2} \alpha \\
\text { with GnRH }\end{array}$ & $\begin{array}{c}\text { Group V } \\
\text { CIDR with } \\
\text { nano } \\
\text { conjugated } \\
\text { GnRH }\end{array}$ & $\begin{array}{c}\text { Group V1 } \\
\text { CIDR, PGF } \alpha \\
\text { with nano } \\
\text { conjugated } \\
\text { GnRH }\end{array}$ & $\begin{array}{l}\text { Group VII } \\
\text { Control }\end{array}$ \\
\hline $\begin{array}{l}\text { On the day of } \\
\text { CIDR } \\
\text { insertion }^{\mathrm{NS}}\end{array}$ & $7.23^{b} \pm 0.17$ & $7.26^{\mathrm{b}} \pm 0.18$ & $7.33^{\mathrm{a}} \pm 0.10$ & $7.45^{b} \pm 0.11$ & $7.39^{b} \pm 0.19$ & $7.42^{\mathrm{b}} \pm 0.17$ & $7.26^{\mathrm{ab}} \pm 0.11$ \\
\hline $\begin{array}{l}\text { On the day of } \\
\text { CIDR } \\
\text { removal }\end{array}$ & $6.99^{\mathrm{ABc}} \pm 0.13$ & $6.71^{\mathrm{Ac}} \pm 0.10$ & $7.06^{\mathrm{Bc}} \pm 0.11$ & $6.77^{\mathrm{ABc}} \pm 0.11$ & $6.81^{\mathrm{ABC}} \pm 0.17$ & $6.88^{\mathrm{ABc}} \pm 0.19$ & $6.80^{\mathrm{ABC}} \pm 0.12$ \\
\hline $\begin{array}{l}\text { On the day of } \\
\text { estrum }\end{array}$ & $8.88^{\mathrm{Bd}} \pm 0.14$ & $8.72^{\mathrm{Bd}} \pm 0.13$ & $8.65^{\mathrm{Bd}} \pm 0.19$ & $8.44^{\mathrm{Bd}} \pm 0.16$ & $8.82^{\mathrm{Bd}} \pm 0.13$ & $8.62^{\mathrm{Bd}} \pm 0.12$ & $8.00^{\mathrm{Ad}} \pm 0.22$ \\
\hline $\begin{array}{l}\text { On the day of } \\
\text { mating NS }\end{array}$ & $7.40^{b} \pm 0.17$ & $7.32^{b} \pm 0.12$ & $7.29^{\mathrm{a}} \pm 0.19$ & $7.38^{b} \pm 0.17$ & $7.42^{b} \pm 0.18$ & $7.55^{\mathrm{b}} \pm 0.11$ & $7.52^{b c} \pm 0.17$ \\
\hline $\begin{array}{c}\text { On the } 70^{\text {th }} \\
\text { day of } \\
\text { Pregnancy }\end{array}$ & $6.53^{\mathrm{a}} \pm 0.26$ & $6.70^{\mathrm{a}} \pm 0.19$ & $6.88^{\mathrm{a}} \pm 0.22$ & $6.70^{\mathrm{a}} \pm 0.16$ & $6.59^{\mathrm{a}} \pm 0.19$ & $6.81^{\mathrm{a}} \pm 0.12$ & $6.76^{\mathrm{a}} \pm 0.26$ \\
\hline
\end{tabular}

Each value is a mean of twenty observations

Means bearing different superscripts in a row (Upper case A,B,..)differ significantly between groups at $5 \% 1(\mathrm{P}<0.05)$

Means bearing different superscripts in a column( small case a,b.c..) differ significantly within groups at $5 \%(\mathrm{P}<0.05)$ and

${ }^{\text {NS }}$-Non significant $(\mathrm{P}<0.05)$

Antunovic et al., (2004) reported that the maternal serum protein concentrations decreased due to increased fetal growth and especially due to utilization of amino acids from the maternal circulation for protein synthesis in the fetal muscles.

In this study, the serum protein values were observed on the day of heat and mating gradually declined on the $70^{\text {th }}$ day of pregnancy and the same may be attributed to the increased consumption of protein for the fetal growth. It is corroborate with the earlier findings of Balikci et al., (2007) and Sema et al., (2009) who reported decreased total protein levels at 150 and 120 days of gestation

The decrease in serum total protein in late pregnancy may be due to the fact that the fetus synthesizes all its proteins from the amino acids derived from its mother, when the growth of the fetus increases exponentially reaching the maximum level (especially in muscles) during late pregnancy (Safsaf et al., 2012).

Das et al., (2014) reported that the mean level of serum total protein decreased significantly $(\mathrm{P}<0.01)$ in ewes during late pregnancy and postpartum suckling $(6.60 \pm 0.17$ and $6.30 \pm$ $0.17 \mathrm{~g} / \mathrm{dL})$, respectively than in premating $(6.90 \pm 0.17 \mathrm{~g} / \mathrm{dL})$.

This study revealed that there is no inter treatment group variation during any stage of the study thereby indicating that the treatment protocols observed did not affect the serum protein level in adverse manner.

Hence, it may be concluded that CIDR, nanoconjugated $\mathrm{GnRH}$ and $\mathrm{PGF}_{2} \alpha$ could be advocated safely to induce Estrus synchronization in Ewes in field condition to enhance the fertility and thereby productivity in sheep. 


\section{References}

Anonymous (2019). 20 $0^{\text {th }}$ All India Livestock Census. Ministry of Animal Husbandry, Dairying and Fisheries. Government of India.

Antunovic, Z., Senei, D., Speranda, M. and Liker,B. (2004). The influence of the season and the reproductive status of ewes on blood parameters. Small Rumin. Res., 45:39-45.

Balikci, E., Yildiz, A. And Gurdogan, F. (2007). Blood metabolite concentrations during pregnancy and postpartum in Akkaraman ewes. Small Rumin Res., 6(7): 247-251.

Das, F., Teleb, A., Nashwa, F., Ahmed, H., Hanan,A., Tag,E.L., Safaa, M., Abououd, E.L. and Omaima, M. (2014). Hassan Study on levels of some blood hormonal and biochemical constituents during different reproductive status in Saidi ewes. Egypt. J. of Sheep and Goat Sci., 9 (3): 105- 113.

Lubran, M,1978. The measurement of Total Serum Proteins by the Biuret Methods, Animals of Clinical and Laboratory Science, Vol. 8 (2): 106- 110.
Safsaf. B., Tlidane, B., Mamache, M.A., Dehini Boukrous and Hassan Aly, A. (2012). Influence of age and Physiological Status on Progesterone and Some Blood Metabolites of Ouled Djellal Breed ewes in East Algeria.Global Veterinaria, 9(2): 237244.

Sema, Y.G., Abuze, K.Z., Nihat and Hasan I.K. (2009). Investigation of some parameters and mineral substance during pregnancy and postpartum period in Awassi ewes. Univ. Vet. Fak Derg., 15 (6): 957-963.

Tamukai, K., Takami, Y., Akabawe, Y., Kama Zarao, Y. and Une, Y. (2011). Plasma biochemical reference values in clinically healthy captive bearded dragons (Pogona vitticeps) and the effects of sex and season. Vet. Clin. Pathol., 368-373.

Yaqub, LS., Ayo, J.O., Rekwot, P.I., Oyeanusi, B.I., Kawu, M.U., Ambali, Shittu, S.F. and Abdullahi, A. (2011).Changes in serum proteins and urea during the estrous cycle in Red Sokoto goats Adv. Appl. Sci. Res., 2(6): 197-205.

\section{How to cite this article:}

Sundara Vinayaki. M., V. S. Gomathi, K. Loganathasamy and Pasupathi, Karu Tanuvas. 2020. Influence of Estrus Synchronization Protocols on Serum Protein during Reproductive Cycle in Kilakarsal Ewes. Int.J.Curr.Microbiol.App.Sci. 9(06): 1754-1757. doi: https://doi.org/10.20546/ijcmas.2020.906.218 